doi: dx.doi.org/10.24866/1560-8425/2020-24/37-52

\title{
Особенности экологии и жизненных циклов водных моллюсков Средней Азии
}

\author{
3.И. Иззатуллаев, Н.А. Рузикулова \\ Самаркандский государственный университет, Республика Узбекистан \\ e-mail:zizzat@yandex.ru; nilruz.sam@mail.ru
}

Рассмотрены особенности экологии водных моллюсков Средней Азии. Представлены оригинальные сведения по биологии 45 видов брюхоногих и двустворчатых моллюсков. Обсуждается влияние на жизненные циклы этих видов температуры, кислородного режима, освещенности, продолжительности безводного периода. Показана прямая зависимость между размерами моллюсков и продолжительностью их жизни.

Ключевые слова: Средняя Азия, брюхоногие, двустворчатые моллюски, экологические группы, жизненный цикл, продолжительность жизни, размножение, генерация.

\section{Patterns of ecology and life cycles of aquatic molluscs from Central Asia}

\section{Zuvaidullo I. Izzatullaev, Nilufar A. Ruzikulova}

Samarkand State University, Republic of Uzbekistan

e-mail:zizzat@yandex.ru;nilruz.sam@mail.ru

Ecological patterns of aquatic mollusks of Central Asia are discussed and reviewed. Original data on biology of 45 gastropod and bivalve species are presented. The effect of temperature, oxygen regime, illumination and duration of waterless periods on mollusk life cycles is discussed. A direct relationship has been shown between the size of molluscs and their lifespan.

Key words: Central Asia, gastropods, bivalves, ecological groups, life cycle, lifespan, reproduction, generation.

Средняя Азия расположена на стыке крупных горных систем и равнин с различными климатическими условиями от умеренных до субтропических. Несмотря на засушливый климат и опустыненные территории, здесь имеются крупные реки Сырдарья, Амударья, Или, Зарафшан (рис. 1) и озера Иссык-куль, Каракуль, Балхаш, Сарез, а также многочисленные мелкие водоемы и подземные источники холодных и теплых вод. Для улучшения водоснабжения еще в советское время построены десятки водохранилищ и каналов (рис. 2). Крупнейшие из них Чарвакское, Нурекское, Капчагайское, Катта-Курганское, Нарынское водохранилища, а также Каракумский, Большой Ферганский, Южный Ферганский, Кайракумский, Куюмазарский каналы. Все эти водоемы характеризуются разнообразием гидрологического, физико-химического и гидробиологического режимов и, соответственно, населены разнообразными моллюсками, изучение которых представляет как теоретический, так и практический интерес. 

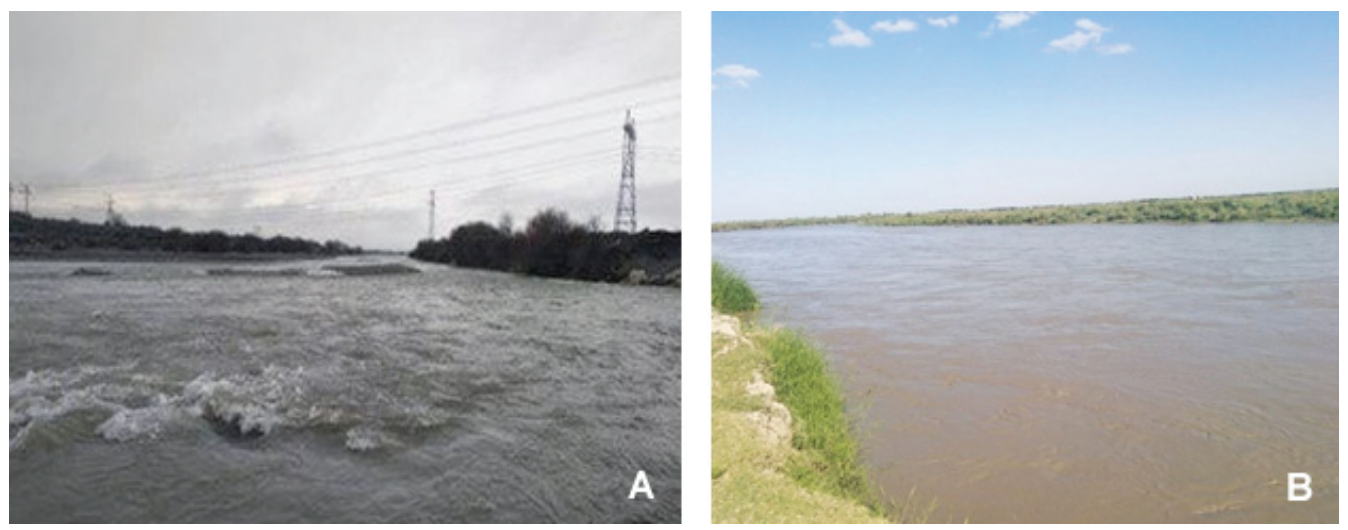

Рис. 1. А - p. Зарафшан в среднем течении (предгорная река); В - р. Зарафшан в нижнем течении (равнинная река). Фото Н. Рузикуловой, 2019 г.

Fig. 1. A - the Middle Zarafshan River (submountain river); B - the Lower Zarafshan River (lowland river). Photo by N. Ruzikulova, 2019.
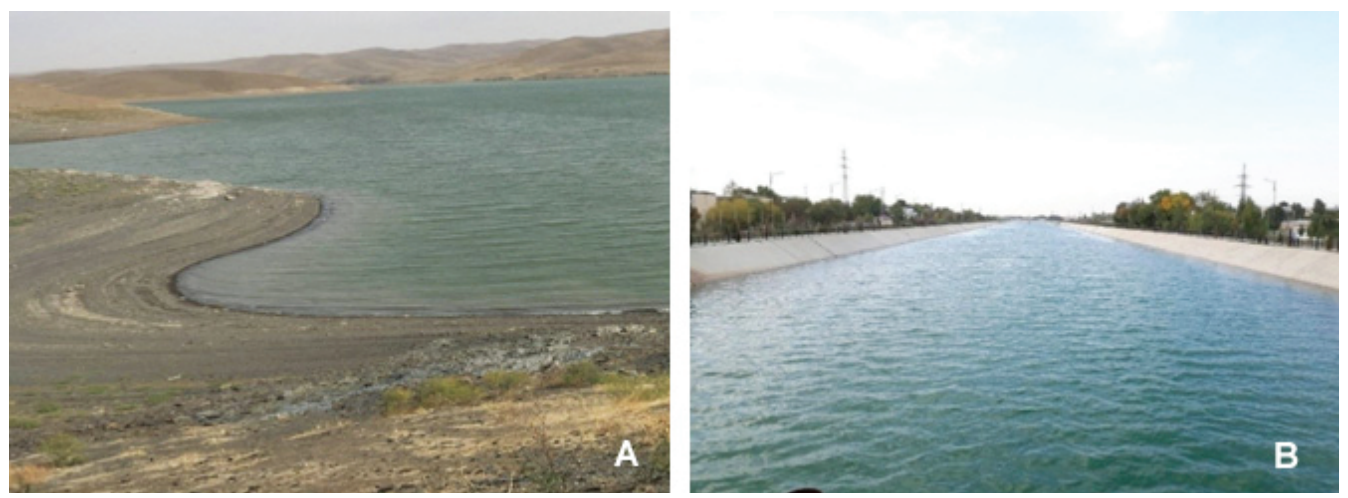

Рис. 2. А - Тусингайское водохранилище; В - оросительный канал Дустлик у г. Гулистан. Фото Н. Рузикуловой, 2020 г.

Fig. 2. A - Tusingay water reservoir; B - irrigation channel Dustlik near the Gulistan Town. Photo by N. Ruzikulova, 2020.

\section{Материалы и методы исследования}

Материалом для исследований послужили сборы моллюсков в период 1967-2016 гг, включающие более 10 тысяч экземпляров из водоемов различных типов в бассейнах рек Сырдарья, Зарафшан и Амударья. Их видовая идентификация проводилась по морфологическим признакам с позиций таксономической школы Я.И. Старобогатова при использовании определителей по фауне СССР и России [Жадин, 1952; Старобогатов и др., 2004], а также собственных работ [Иззатуллаев, 1980, 1987; Иззатуллаев и др., 1983; и др.]. 
Возраст крупных двустворчатых моллюсков Sinanodonta Modell, 1944, Colletopterum Bourguignat, 1881, Corbiculina Dall, 1903 и Corbicula Megerle, 1811 определяли путем подсчета годовых колец (остановок роста) с учетом данных А.Ф. Алимова [1981], который исследовал возраст этих животных в Средней Азии. У гребнежаберных моллюсков возраст определяли по количеству утолщенных линий на крышечке раковины. Пол Unionidae устанавливали по консистенции половых продуктов (у самцов однородно-мутная, а у самок - зернистая). У гребнежаберных брюхоногих учитывали проявление полового диморфизма формы раковины [Иззатуллаев, 1987, 2019]. Число генераций отмечали в природе и в лаборатории по методу Г. В. Березкиной и Я. И. Старобогатов [1988].

\section{Результаты исследования и обсуждение}

В разнотипных водоемах Средней Азии в ходе многолетних исследований зарегистрированы 208 видов и 9 подвидов моллюсков, относящихся к 12 экологическим группам [Иззатуллаев, 1987, 2017, 2019]. Среди этих групп фитофилы представлены следующими видами: Lymnaea stagnalis (L., 1758), L. fragilis (L., 1758) (рис. 3), L. auricularia (L., 1758), Costatella acuta (Drap., 1805), C. integra (Haldeman, 1841), Planorbis planorbis (L., 1758), $P$. tangitarensis (Germain, 1918). К кренофилам отнесены представители родов Buchramnicola Izzatullaev, Sitnikova et Starobogatov, 1985, Turkmenamnicola Izzatullaev, Sitnikova et Starobogatov, 1985, Valvatamnicola Izzatullaev, Sitnikova et Starobogatov, 1984, обитающие в холодных источниках, а также термокренофилы из теплых источников Melanoides kainarensis (Starobogatov et Izzatullaev, 1980), M. pamiricus (Lindholm, 1930), M. shahdaraensis (Starobogatov et Izzatullaev, 1980) (рис. 4) и Lymnaea alticola (Izzatullaev,
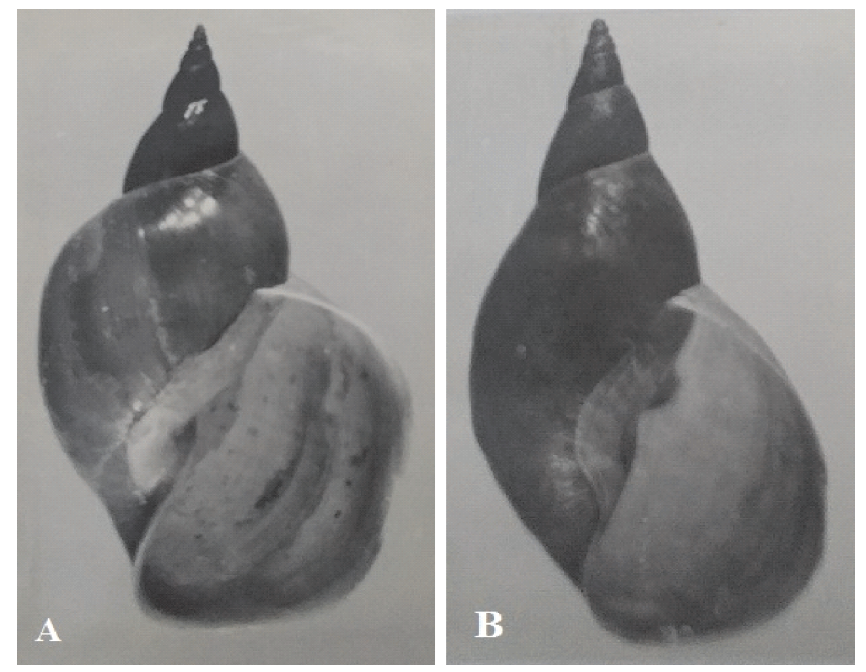

Рис. 3. Раковины Lymnaea s.str. из Кайраккумского водохранилища: A - Lymnaea stagnalis (L.), высота раковины 5.2 мм; B - L. fragilis (L.), высота раковины 22 мм. Фото 3. Иззатуллаева, 1971 г.

Fig. 3. Shells of the Lymnaea s.str. Species from the Kairakkum water reservoir: A - Lymnaea stagnalis (L.), shell height $5.2 \mathrm{~mm}$; B - L. fragilis (L.), shell height $22 \mathrm{~mm}$. Photo by Z. Izzatullaev, 1971. 

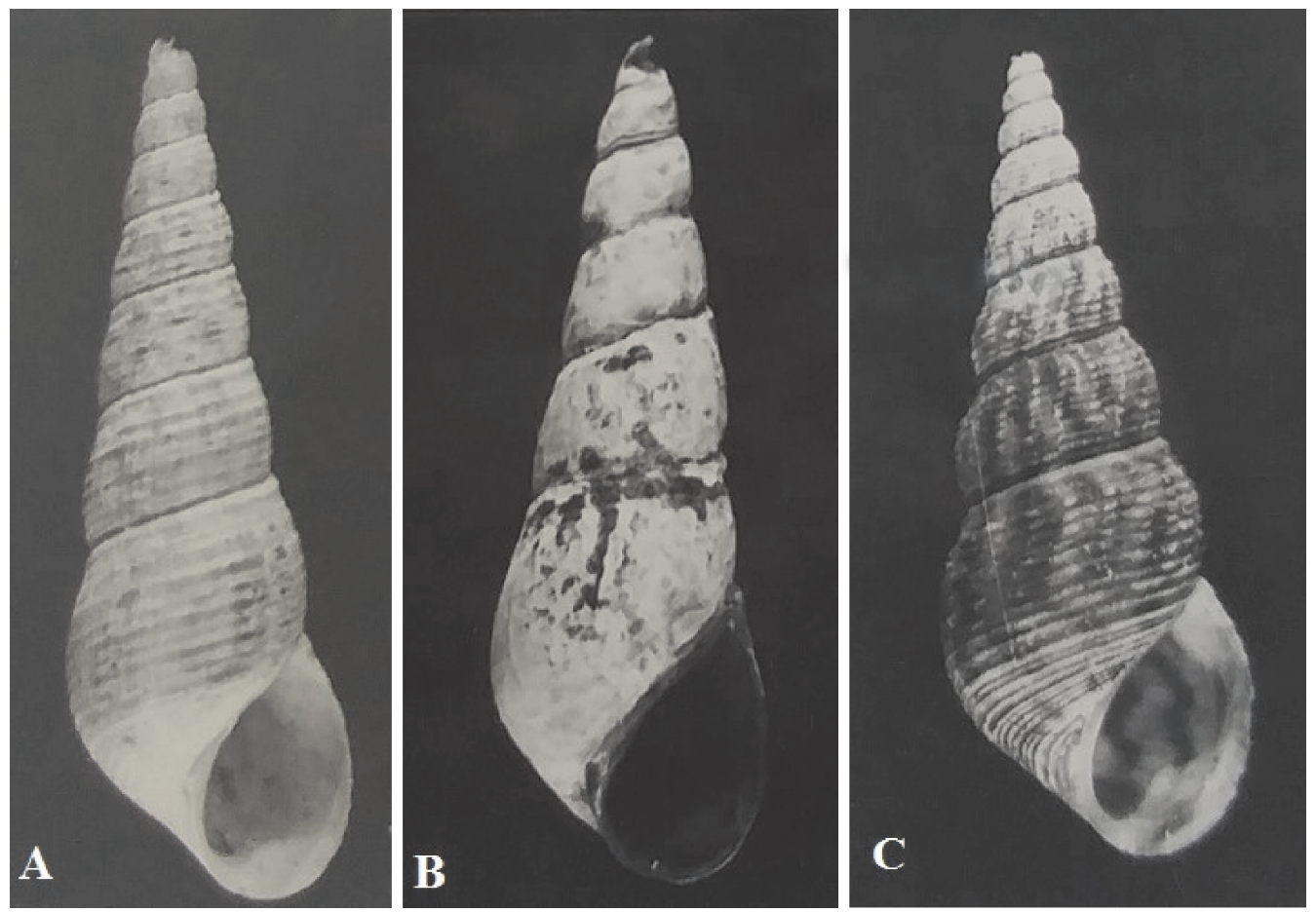

Рис. 4. Раковины видов Melanoididae из термальных источников: $\mathbf{A}$ - Melanoides pamiricus Lindholm из теплого источника Джаушангоз (Памир), высота раковины 16 мм; В - M. shahdaraensis Starobogatov et Izzatullaev, из теплого источника Джаушангоз, высота раковины 15 мм; C - M. kainarensis Starobogatov et Izzatullaev из теплого источника Хаджа-Кайнар (юго-восток Туркмении), высота раковины 23 мм. Фото 3. Иззатуллаева, 1976, 1980 гг.

Fig. 4. Shells of the Melanoididae species from thermal springs: A - Melanoides pamiricus Lindholm, the hot spring Dzhaushangoz (Pamir), shell height $16 \mathrm{~mm}$; B - M. shahdaraensis Starobogatov et Izzatullaev, the hot spring Dzhaushangoz, shell height $15 \mathrm{~mm}$; C - M. kainarensis Starobogatov et Izzatullaev, the hot spring Khadzha-Kainar (south-eastern Turkmenistan). Photo by Z. Izzatullaev, 1976, 1980.

Kruglov et Starobogatov, 1983). Тельматофилы, приуроченные к лужам, и экологически сходные с ними обитающие на мокрых поверхностях мадиколы L. truncatula (Muller, 1774), L. goupili (Maquin-Tandon, 1855), L. subangulata (Roffiaen, 1868), L. thiesseae (Clessin, 1879), L. schirazensis (Kuster, 1962) [Иззатуллаев, 1987, 2017, 2019].

Наиболее разнообразны фитофилы, число видов которых составляет около четверти (24\%) от общего видового списка. Далее по убывающей следуют кренофилы (13\%), пело-псаммореофилы (9\%), пело-псаммолимнофилы (5\%) и тельматофилы (5\%). К наиболее малочисленным относятся обнаруженные в подземных водах региона (озеро Карлюкских пещер в Туркмении) пелофильные троглобионты и мадиколы, обитающие на мокрых каменистых или глинистых берегах рек, стенки дренажных каналов и мокнущих скал. 
Отдельно следует рассмотреть обитателей малых водоемов, где нерегулярное поступление воды часто перекрывается испарением и водоемы пересыхают. По этому признаку малые водоемы разделяются на иссыхающие (сухие большую часть года), эфемерные (высыхающие летом более чем на три месяца), периодические (высыхающие летом на 1-3 месяца) и полупостоянные (пересыхающие на период до одного месяца). К типичным обитателям малых водоемов Средней Азии относятся 15 видов. Для иссыхающих водоемов характерны Planorbarius stenostoma (Bourguignat in Servain, 1881), Lymnaea kazakensis (Mozley, 1934), L. subdisjuncta; эфемерных - L. truncatula, L. subangulata; периодических - L. truncatula, L. subangulata, L. hookeri (Reeve, 1850), P. planorbis, Anisus ladacensis (Nevill, 1878), Aplexa hypnorum (L., 1758); полупостоянных - Cincinna umbilicate (Fitzinger, 1833), L. lagotis, L. subdisjuncta, L. iliensis (Lazareva, 1967), L. saridalensis (Mozley, 1934), L. terebra bolotensis (Mozley, 1934), A. ladacensis и эврибионтный Euglesa turkestanica (Izzatullayev, 1974).

Моллюски из пересыхающих водоемов обладают рядом биологических особенностей, обеспечивающих их выживание в безводной период. Отдельные обитатели малых водоемов переносят отсутствие воды в течение 80-100 дней [Klimowicz, 1959]. По данным Н.М. Акрамовского [1976], в Араратской долине Армении L. truncatula переживают даже девятимесячное пересыхание водоемов, образуя на устье эпифрагму из высохшей слизи. Катушки P. planorbis, A. ladacensis могут формировать до четырех эпифрагм, приклеиваясь ими к грунту или растительности. Для физиды A. hypnorum и других Aplexinae обсыхание служит стимулом для откладки яиц, собранных в слизистые синкапсулы, которые более засухоустойчивы, чем сами улитки [Березкина, Старобогатов, 1988; Прозорова, 1991].

Осенью при остывании водоемов моллюски перемещаются в более глубокие места, зарываются в ил или вновь закрывают раковину различными способами, также замедляя жизнедеятельность. Это позволяет моллюскам во время ледостава переносить недостаток растворенного в воде кислорода, накопление углекислоты и даже промерзание, что отмечено у L. fontinalis, L. narzykulovi (Izzatullaev, Kuglov et Starobogatov, 1983), A. ladacensis, A. pancongensis и некоторых других видов. Мы наблюдали это в водоемах Восточного Памира в пойме р. Аличур для L. fontinalis и в оз. Турумтайкуль на высоте 4200 м над уровнем моря для L. narzykulovi. Аналогичные данные содержаться и в работе В.И. Жадина [1952], который отмечает, что осенью при похолодание моллюски стремятся уйти в глубь водоема, лишь немногие брюхоногие остаются у уреза воды и ползают по нижний поверхности льда. Зарываясь в грунт, они впадают в оцепенение, так что при температуре $2-5^{\circ} \mathrm{C}$ число сердцебиений снижается до 3-4 в мин. Весной катушки и прудовики могут оттаивать и возобновлять жизнедеятельность за счет природного антифриза в их гемолимфе [Жадин, 1952; Вундцеттель, 2005], что мы неоднократно наблюдали в своем регионе. 
В большинстве постоянных водоемов встречаются моллюски нескольких экологических групп. В ряде случаев соотношение этих групп больше говорит об особенностях водоема, чем наличие узкоспециализированных видов [Березкина, Старобогатов, 1988]. В Средней Азии из-за нестабильности грунтов и мутности воды равнинные участки рек крайне бедны моллюсками, например, низовья р. Заравшан (рис. 1). Здесь очень редки фитофильные моллюски, например, прудовики из семейства Lymnaeidae, катушки Planorbarius Dumeril, 1806 и др. При этом основная масса моллюсков сосредоточена в больших и малых заводях, оросительных каналах и водохранилищах (рис. 2), где наиболее обычны пелореофилы Colletopterum cyreum sogdianum (Kobelt, 1896), Sinanodonta gibba (Benson, 1855), Corbiculina ferghanensis (Kursalova et Starobogatov, 1971) и др.

Экологические группировки моллюсков региона неравномерно распределены вдоль русла рек от высокогорных верховий до долинных низовий. Для высокогорий характерны представители Euglesidae (14 видов), Pisidiidae (6 видов), Planorbidae (6 видов) и Lymnaeidae (5 видов). Фауна моллюсков долин и низкогорий гораздо разнообразнее. Здесь обитают представители 14 семейств, среди которых преобладают Pseudocaspiidae (8 видов), Unionidae (8 видов), Melanopsidae (6 видов), Corbiculidae (5 видов). Такое разнообразие видового указывает на обилие здесь биотопов для развития теплолюбивых и эврибионтных видов [Иззатуллаев, 1983, 1987].

Протекание жизненного цикла моллюсков в том или ином водоеме во многом определяются конкретными экологическими условиями. Одним из основных внешних факторов, влияющих на продолжительность жизни моллюсков, является годовой ход температуры, которая также регулирует репродуктивные процессы. Именно повышения температуры воды, особенно внезапные, чаще всего стимулируют у пульмонат (особенно у прудовиков Lymnaeidae) овипозицию [Joosse et al., 1968]. Температура влияет (ускоряет или замедляет) не только на рост и размножение, но и на распределение моллюсков по глубине в пределах водоема. Интенсивность питания, темп роста и незначительные миграции моллюсков также зависят от годового хода температуры воды. Весной с постоянным увеличением температуры воздуха и воды в водоемах моллюски начинают расти, летом их рост достигает максимума, осенью замедляется, а зимой полностью прекращается. В водоемах Средней Азии, где летние температуры более высоки и устойчивы, раковины у L. stagnalis, L. auricularia, L. bactriana (Hutton, 1850) и C. acuta более крупные, чем в водоемах высокогорий с более низким и неустойчивыми температурами.

Цикличность размножения моллюсков обитающих в водоемах Средней Азии, подчиняется законам вертикальной и широтной зональности. При этом длительность периода размножения прямо пропорциональна сумме эффективных температур исследованных территорий. Этой же закономерности подчиняется и количество генераций за вегетационный период, что можно проследить 
на примере $C$. acuta, C. integra, L. truncatula. В водоемах окрестностей г. Душанбе в теплые годы они дают 3-4 генерации с апреля до конца ноября, а в горах 1-2 генерации с конца июня до начала августа.

В Средней Азии имеются водоемы с большими глубинами и выраженной температурной стратификацией и наличием батиали - озера Арал, Иссык-куль и Яшилькуль. В прибрежье оз. Иссык-Куль на различных глубинах в массе обитают эндемичный Pseudocaspia issykkulensis (Clessin, 1894) и центрально-азиатский Lymnaea obliquata (Martens, 1864). Последний, по данным М.В. Павловой [1983], на мелководье озера размножается с конца апреля по середину мая при температуре $8.5-10^{\circ} \mathrm{C}$, а на глубинах $25-80$ м гораздо позже, в июле. Причем это единственный вид лимнеид Средней Азии, ведущий исключительно подводный образ жизни, извлекая кислород из воды с помощью его мантийных выростов.

Другим примером воздействия температурного фактора является распределение беззубок в поперечном сечении русла р. Сырдарьи, где в более теплом прибрежье плотность популяций C. cyreum sogdianum составляло 2.69 экз./ $\mathrm{M}^{2}$, а в меженной, более прохладной зоне только 1.8 экз./м² [Пивцаев и др., 2001].

Кроме температуры, большое значение для моллюсков имеет доступность кислорода [Березкина, Старобогатов, 1988; и др.]. Легочный способ дыхания объясняет известную приуроченность пульмонат к малым водоемам и прибрежьям более крупных. Легочные с доминирующим кожным дыханием и жаберные моллюски, использующие растворенный кислород, наиболее обильны на участках с хорошей аэрацией воды независимо от субстрата (грунт, растительность, погруженные предметы). Известно, что из пульмонат акролоксиды не используют атмосферный кислород, в частности, отмеченный в Средней Азии Acroloxus lacustris (L., 1758). Кожное дыхание преобладает у лимненид L. fontinalis (Studer, 1820). Виды L. auricularia, L. psilia (Bourgignat, 1862) сочетают легочное и кожное дыхание. Легочное доминирует у L. stagnalis $u$ L. fragilis, обитающих в массе по берегам Кайраккумского водохранилища и в дельте р. Амударьи, они присутствуют в пределах зарослей тростника [Иззатуллаев, 1987, 2019].

Продолжительность и интенсивность освещения, как известно, регулирует у гастропод откладку яиц [Березкина, Старобогатов, 1988]. На равнинах Средней Азии в условиях раннего потепления моллюски приступают к размножению в начале марта, при более позднем приходе весны - в конце марта или в начале апреля. При этом представители рода Melanoides Olivier, 1804 (рис. 4), виды L. alticola, L. fontinalis из горячих источников Памира (Таджикистан, температура воды $26-32^{\circ} \mathrm{C}$ ) и Кугитанга (Туркмения, температура воды 20-22 ${ }^{\circ} \mathrm{C}$ ) размножаются круглый год [Иззатуллаев и др., 1983; Старобогатов, Иззатуллаев, 1980]. В.И. Жадин [1952] сообщает о находке живых L. truncatula и их кладок в горячем источнике Ходжа Обигарма в Таджикистане при температуре $32^{\circ} \mathrm{C}$. Однако жизнедеятельность большинства видов при высоких температурах воды из-за усиленного прогревания водоемов летом угнетается, но осенью наступает новый период размножения, хотя и менее интенсивный, чем весной. 
Для разных видов характерны свои условия, при которых они наиболее активно растут и размножаются. Например, заносной представитель семейства Physidae C. integra в Душанбе и его окрестностях, а также L. truncatula из местных оросительных каналов в благоприятные годы приступают к размножению в первой половине марта, а на юге Таджикистана в Вахшской долине еще раньше. У физиды C. acuta на равнинах первые кладки отмечены в начале апреля. В течение 10-15 дней (в лабораторных условиях 15-18 дней) из яиц вылупляется молодь, раковина которой насчитывает 1.5-2.0 оборота. Продолжительность жизни составляет 2-3 года. Как уже упоминалось, этот вид на равнине даёт 3-4 поколения, а в высокогорьях лишь 1-2. Более крупные уховидные прудовики Lymnaea subdisjuncta (Nevill, 1878) и L. bactriana на равнинах размножаются при более высоких температурах, чем физиды, с конца апреля - начала мая до июня.

Прудовик L. stagnalis на равнинах размножается все лето, в горах с конца июля и начало августа. В кладках насчитывается до 200 яиц [Иззатуллаев, 2009]. О.В. Левина [1975] для Киевского водохранилища (Украина) отмечает, что определяющим факторам частоты откладки яиц у обыкновенного прудовика является температура. У близкого вида L. fragilis с меньшей продолжительностью жизни размножение наблюдается в июне-августе, а к лету следующего года новая генерация уже приступает к размножению.

Представители двустворчатых моллюсков подсемейства Anodontinae, как и в других регионах Палеарктики, размножаются осенью [Иззатуллаев, 2019]. У C. cyreum sogdianum формирование яиц в жабрах происходит в сентябре, а в октябре мы уже находили их глохидии, паразитирующие на рыбах. Эти сроки также подтверждаются исследованиями Н.Н. Гаркаловой [1969] в Кайруккумском водохранилище на севере Таджикистана. Аналогичные данные имеются и по срокам размножения корбикулиды C. ferghanensis [Березкина, Старобогатов, 1988; Курсалова, Старобогатов, 1971].

На основании изучения морфологии раковины, строения замков, размножения и распространения у среднеазиатских Corbiculidae выявлены роды Corbicula Megerle, 1811 и Corbiculina Dall, 1903 [Иззатулаев, 1980; Корнюшин, 2004; Старобогатов и др., 2004]. Род Corbicula в Средней Азии представлен тремя видами: C. cor (Lamarck, 1818), C. fluminalis (O.F. Muller, 1774) и C. purpurea (Prime, 1864). Все они, кроме водоемов равнин Средней Азии, широко распространены в Закавказье и в странах Передней Азии (Сирия, Израиль, Ирак, Иран на восток до Сеистана). Эти континентальные виды относятся к эстуарным формам, но в отличие от них характеризуются внутренним оплодотворением с коротким периодом вынашивания на жабрах яиц с велигерами и выметыванием в воду очень мелких, но уже трансформированных ювенилов, подобно пресноводному исходно восточно-азиатскому C. fluminea (O.F. Müller, 1774).

Род Corbiculina включает два яйцеживородящих вида - C. ferghanensis (Kursalova et Starobogatov, 1971) и C. tibetensis (Prashad, 1929). Находка ювенильных раковин в мантийной полости взрослых особей [Иззатуллаев, 1980] 
подтверждает их принадлежность роду Corbiculina, виды которого вынашивают молодь на жабрах до заметных размеров [Habe, 1977].

По продолжительности жизни среднеазиатские моллюски могут быть разделены на несколько групп - от живущих менее одного года до десяти лет (см. таблицу). Среди брюхоногих, например, менее одного года живут самые мелкие в регионе гребнежаберные моллюски родов Martensamnicola, Valvatamnicola, Sogdamnicola, тогда как наиболее крупные представители того же подкласса из родов Melanoides и Melanopsis Ferussac, 1807 живут до шести лет [Старобогатов, Иззатуллаев, 1980; Иззатуллаев, 1987, 2019]. Жизненный цикл наиболее крупных прудовиков Lymnaeidae обычно занимает 2-3 года [Лазарева, 1967], однако в наиболее теплых районах Средней Азии L. stagnalis доживает до пятилетнего возраста, достигая половой зрелости в течение 130 дней. О.В. Левина [1975] для Киевского водохранилища также отмечает, что обыкновенный прудовик здесь становится половозрелым в возрасте 130 дней. Близкий вид L. fragilis живет обычно не более трех лет, никогда не доживая до четырехлетия.

Несколько менее крупные прудовики подрода Radix живут чаще всего 1.5-2.5 года. Например, продолжительность жизни L. bactriana из оз. Иссык-куль составляет 2-2.5 года, а размножение протекает с апреля по декабрь [Павлова, 1964]. Однако обитающий в термальных водах Памира L. alticola (теплые источники Иссык-Куль, Яшилькуля на высоте 3800 м над уровнем моря и другие 6 источников) живет чуть больше одного года, размножаясь независимо от сезона. Также короток (не более полутора лет) срок жизни самых мелких Galbaобразных прудовиков. Из девяти среднеазиатских видов, входящих в этот подрод, самый массовый L. truncatula за время жизни в условиях равнин успевает дать до трех поколений, а в прохладном высокогорье не более двух.

Мелкие представители семейства Planorbidae живут не более одного года. Виды Anisus pancongensis (Nevill, 1878) и A. albopersicus (Germain, 1918), обитающие в теплых источниках, дают до 4-х генераций в ходе своего годового жизненного цикла. Продолжительность жизни более крупных планорбид (P. planorbis, P. tangitarensis, P. sieversi (Mousson, 1873)) составляет от года до полутора лет, в течение которых сменяются 2-3 периода размножения.

Среди двустворчатых моллюсков Средней Азии наибольшей продолжительностью жизни обладают пресноводные Unionidae [Старобогатов и др., 2004]. У родов Sinanodonta и Colletopterum, живущих десять и более лет, в условиях Средней Азии, как и в других регионах, глохидии выметываются летом (июньавгуст), хотя яйца оплодотворяются в жабрах еще предыдущей осенью. Менее крупные Corbiculidae также размножаются в июне-августе, однако продолжительность их жизни не превышает шести лет [Старобогатов и др., 2004; Иззатуллаев, Боймурадов, 2009]. А.Ф. Алимовым [1981] были рассчитаны параметры роста C. purpurea, C. tibetensis и C. fluminalis из Средней Азии и Закавказья. Наибольшая продолжительность жизни отмечена у C. fluminalis, которые характеризуются низкой скоростью роста. 


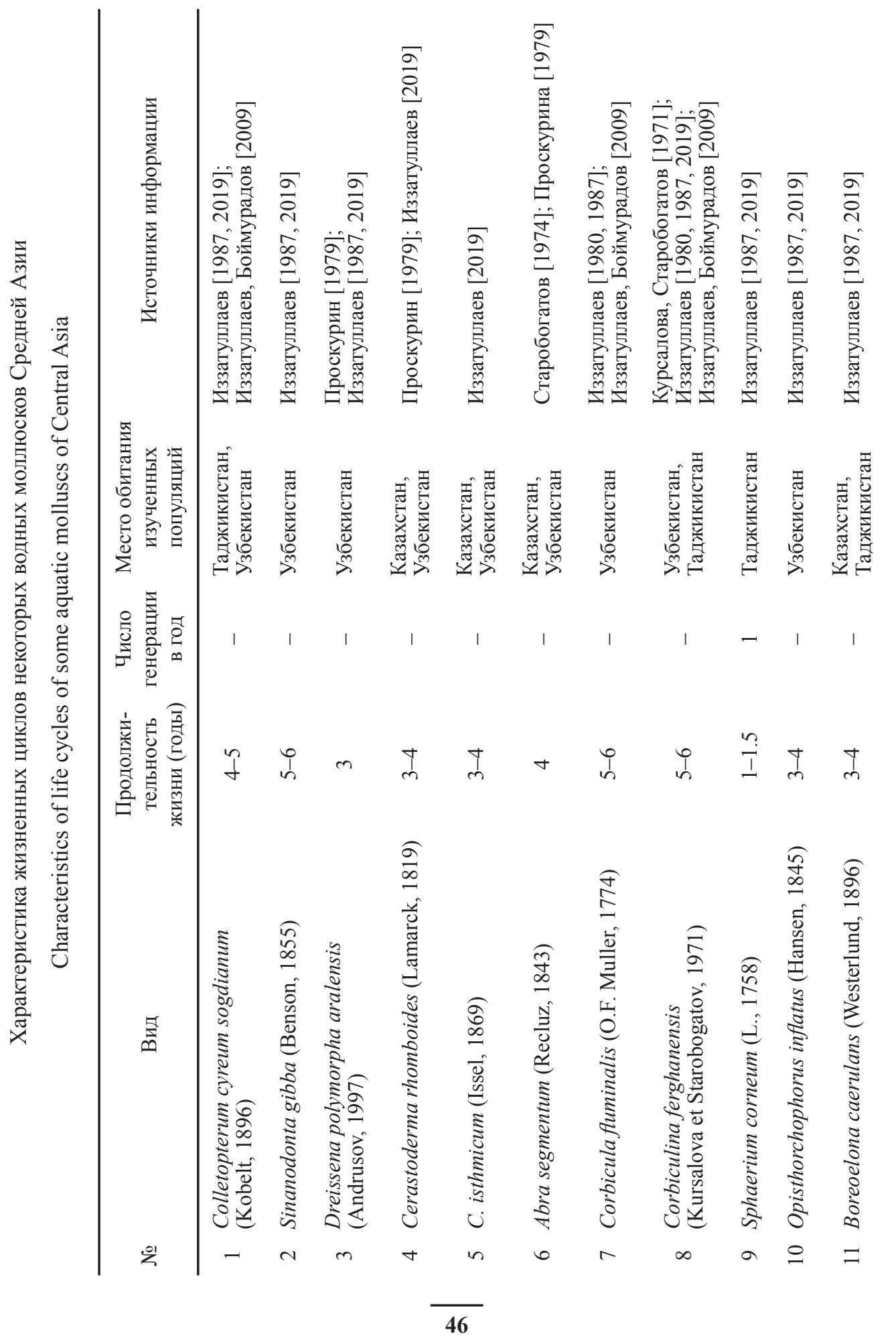




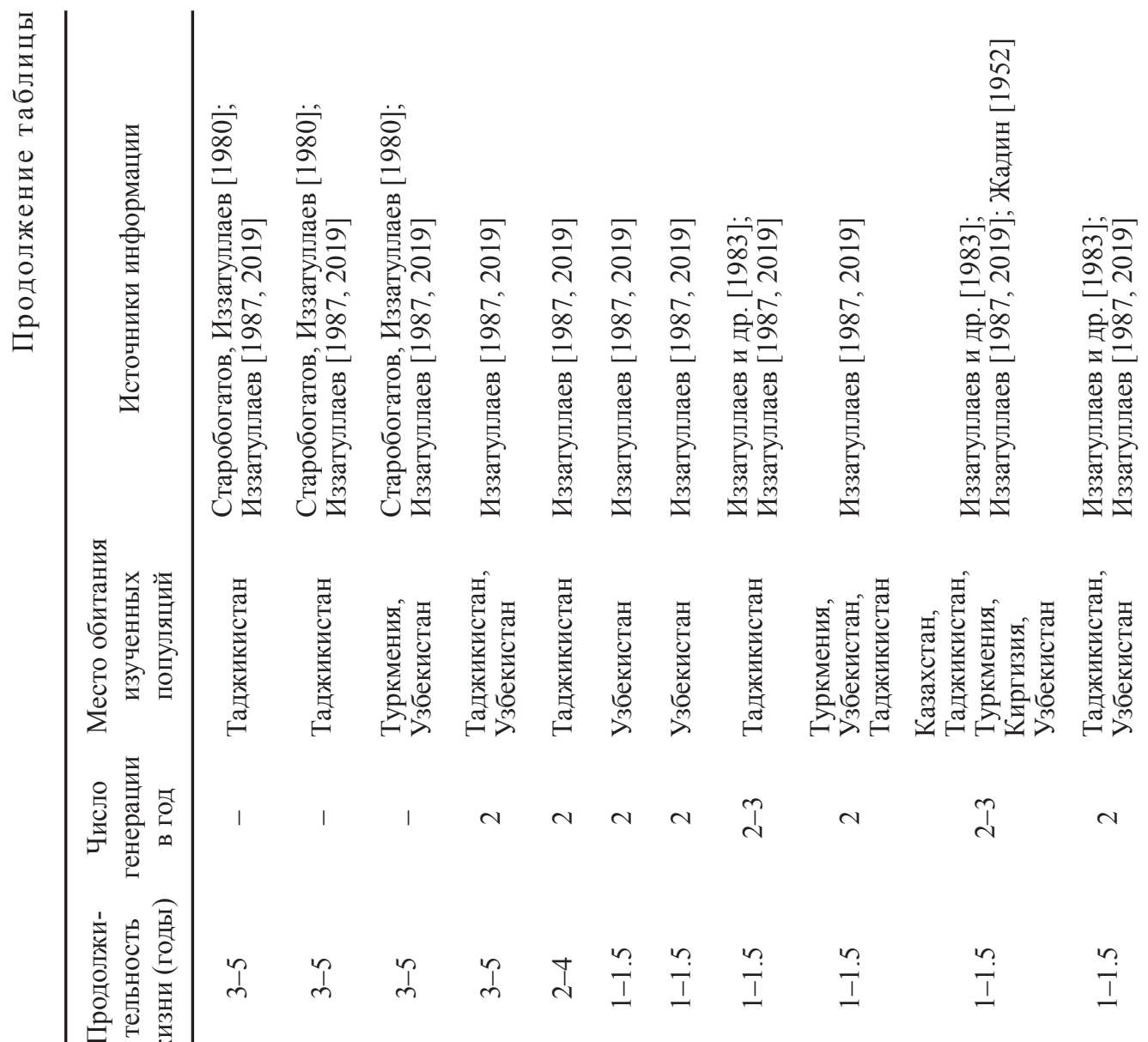




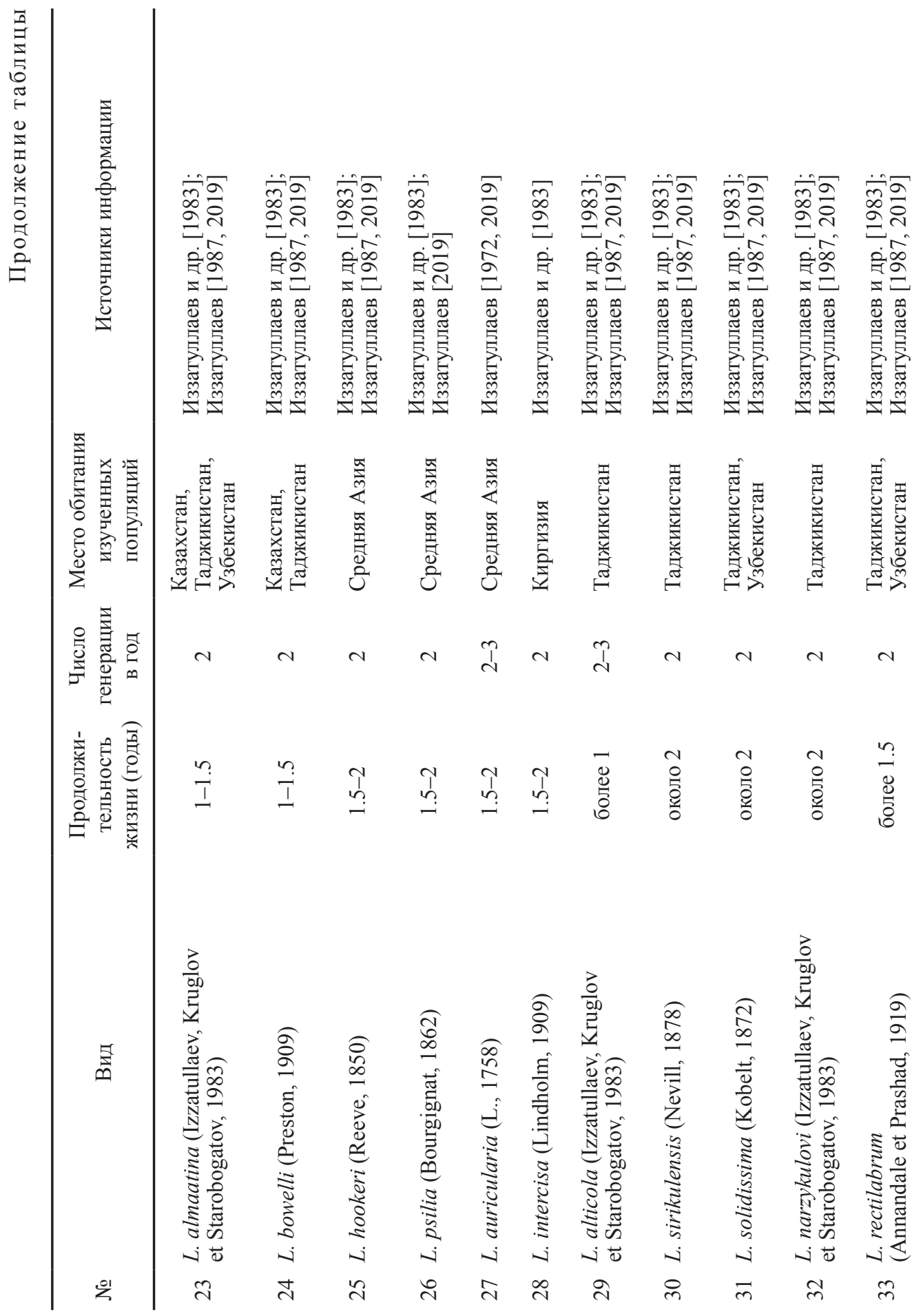




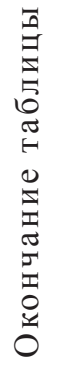
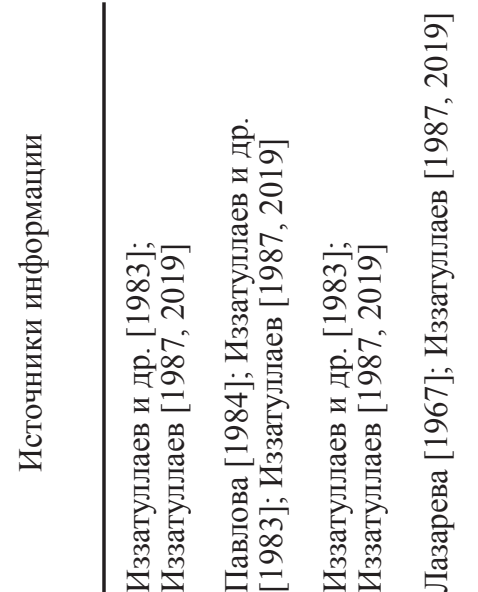

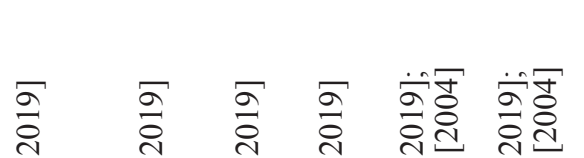

용

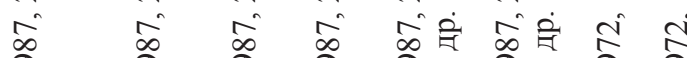

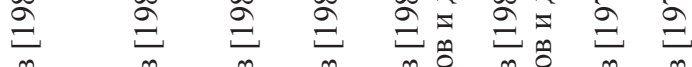

营

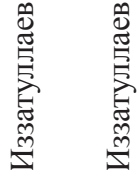

莺

氮

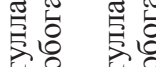

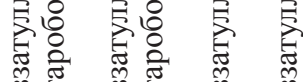

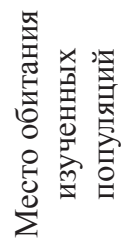

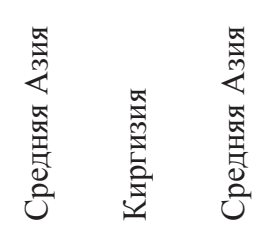

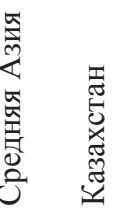

政

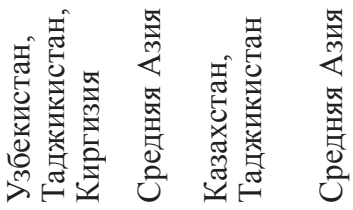

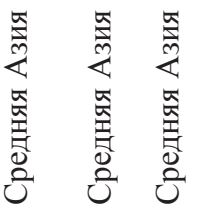

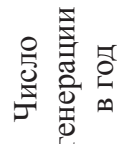

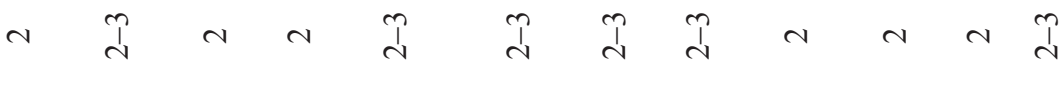

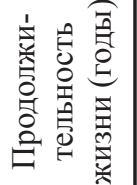

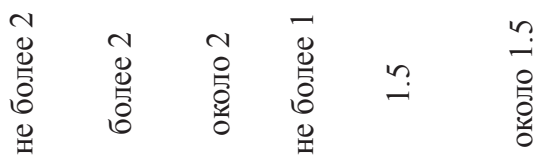

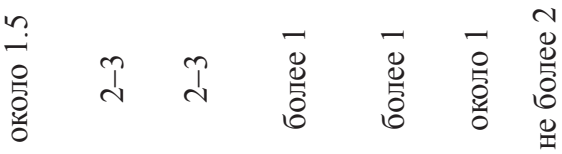

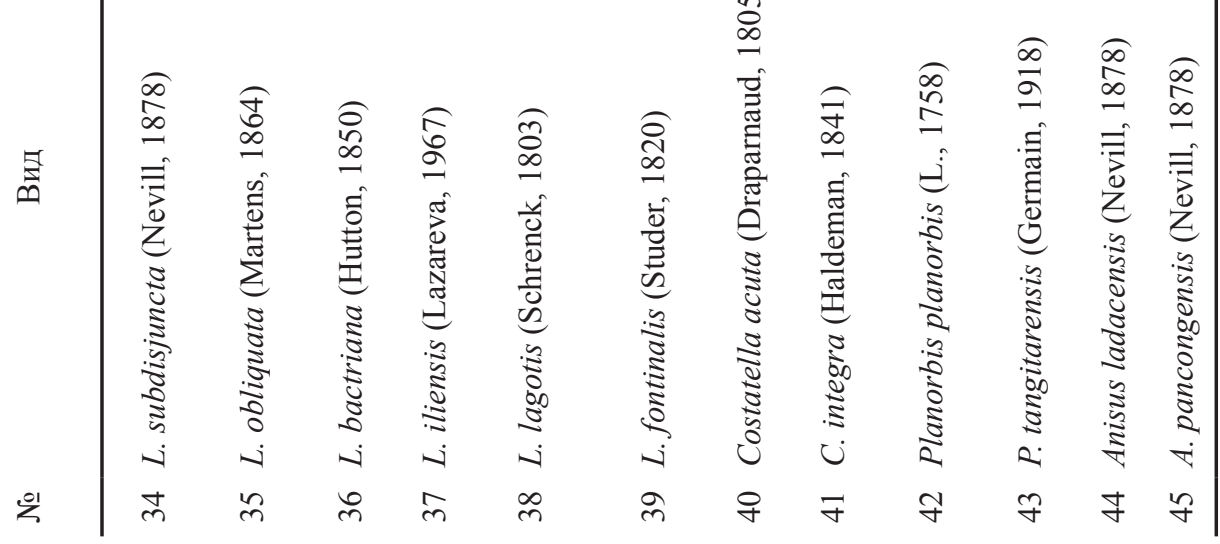

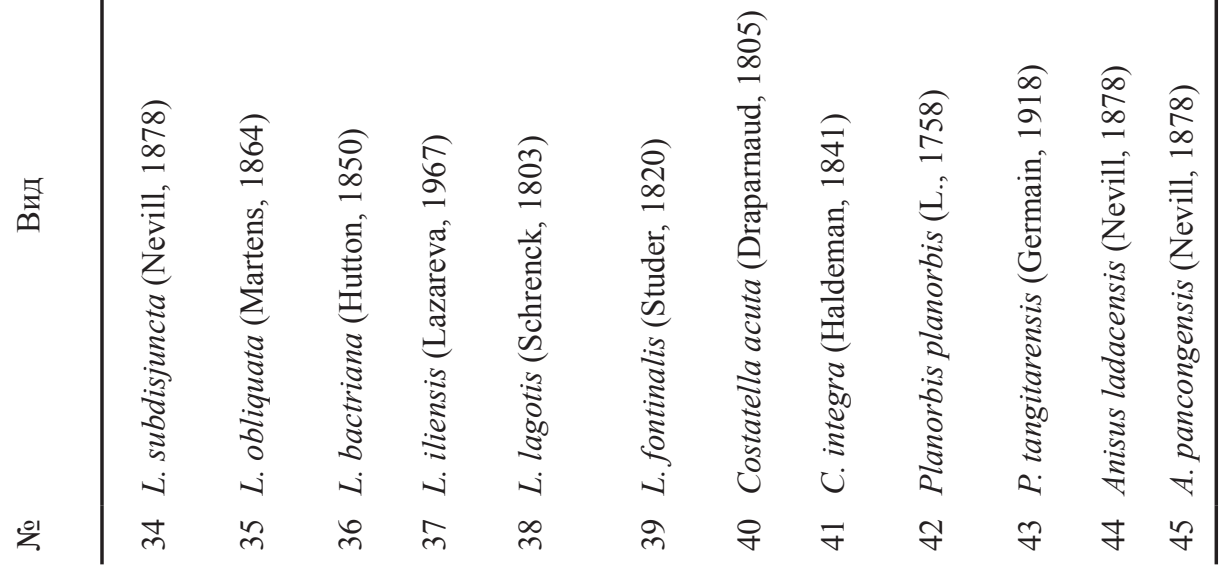


Солоноватоводные двустворки семейств Lymnocardiidae (Cerastoderma rhomboides (Lamarck, 1819), C. isthmicum (Issel, 1869)) живут 3-4 года [Старобогатов, 1974; Хусаинова, 1954; Андреева, 2000], а Scrobiculariidae, в частности Abra segmentum (Reclus, 1843), 4 года [Проскурина, 1979], давая летом по одной генерации в год.

Мелкие пресноводные шаровки и горошины родов Sphaerium Scopoli, 1777, Euglesa Leach in Jenyns, 1832, Odhneripisidium Kuiper, 1962, Pisidium Pfiffer, 1821, являющиеся гермафродитами, обладают самым коротким среди среднеазиатских бивальвий однолетним жизненным циклом. В течение жизни они дают одну генерацию, но на юге иногда две. У кренофила Kuiperipisidium terekense (Kazannikov in Izzatullaev et Starobogatov, 1986) в жабрах материнской особи встречались до 11 ювенилов. У Odhneripisidium chatyrkulense (Izzatullaev et Starobogatov, 1986) из горных озер и родников (2000 м над уровнем моря) в конце июня-августе в жабрах отмечено по 4-5 эмбрионов, у Euglesa obliquata (Clessin, 1874) - 4-20, у E. turkestanica (Izzatullaev, 1974) - 4-9, у E. heldreichi (Clessin, 1874) из Иссык-Куля - 8-16; т.е. в отличие от тысяч ювенилов и личинок, отрождаемых крупными двустворками, потомство среднеазиатских Sphaeriidae весьма малочисленно.

Таким образом, у двустворчатых моллюсков Средней Азии, как и у брюхоногих, в большинстве случаев наблюдается прямая зависимость между размерами и продолжительностью жизни моллюсков, что уже отмечалось ранее [Алимов, 1981].

\section{Заключение}

По экологическим предпочтениям среди 208 видов и 9 подвидов водных моллюсков Средней Азии преобладают широко распространенные фитофилы (24\%), кренофилы, живущие в ключах и родниках (13\%), а также обитающие в реках и озерах пело-псаммофилы (9\%). В малых водоемах Средней Азии отмечены 15 видов моллюсков, которые в разных сочетаниях характерны для иссыхающих, эфемерных, периодических и полупостоянных водоемов.

Среди легочных брюхоногих большинство видов обладает одно-двухлетним жизненным циклом и только наиболее крупные прудовики Lymnaea s. str. живут до пяти лет. Жизненный цикл мелких жаберных моллюсков завершается за 1-2 года, но более крупные Bithyniidae и Melanoididae живут 3-5 лет. Число генераций у гастропод чаще всего не больше двух в год, но у отдельных мелких видов доходит до четырех и даже до пяти при обитании в термальных водоемах. На равнинах размножение брюхоногих происходит в марте-июне, а в более прохладном высокогорье - в июле-августе. Гастроподы, обитающие в теплых источниках, размножаются независимо от сезона и характеризуются сокращенным жизненным циклом. 
Среди двустворчатых моллюсков Средней Азии представители Unionidae как самые крупные доживают до 10 лет. Несколько меньшие по размерам виды семейств Lymnocardiidae, Scrobiculariidae и Corbiculidae живут, соответственно, до трех, четырех и шести лет, а самые мелкие Sphaeriidae обладают годичным жизненным циклом.

Таким образом, у большинства водных моллюсков Средней Азии наблюдается прямая зависимость между их размерами и продолжительностью жизни. Исключение составляют обитатели термальных вод, обычно совершающие ускоренный жизненный цикл.

\section{Благодарности}

Авторы искренне благодарны редколлегии и рецензентам за ценные замечания, дополнения и языковую адаптацию текста.

\section{Литература}

Акрамовский Н.H. 1976. Моллюски (Mollusca). Фауна Армянской ССР. Ереван: Изд-во АН АрмССР. $272 \mathrm{c}$.

Алимов А.Ф. 1981. Функциональная экология пресноводных двустворчатых моллюсков. Л.: Наука. $243 \mathrm{c}$.

Андреева С.И. 2000. Современные Cerastoderma (Bilvalvia, Cardiidae) Аральского моря. Систематика, изменчивость, эволюция. Омск: Изд-во ОмГПУ. 240 с.

Березкина Г.Н., Старобогатов Я.И. 1988. Экология размножения и кладок яиц пресноводных легочных моллюсков // Труды Зоологического института АН СССР. Т. 174. С. 1-307.

Вундиеттель М.Ф. 2005. Общая гидробиология. Астрахань: АГТУ. 156 с.

Гаркалова Н.Г. 1969. Формирование паразитофауны рыб Кайраккумского водохранилища. Автореф. дисс. ... канд. биол. наук. Л. 17 с.

Жадин В.И. 1952. Моллюски пресных и солоноватых вод СССР. М.-Л.: Изд-во АН СССР. 376 с.

Иззатуллаев 3.И. 1977. К фауне пресноводных моллюсков Гиссарского хребта сопредельных районов Таджикистана // Известия АН Таджикской ССР. Отделение биологических наук. № 3(48), C. 44-49.

Иззатуллаев 3.И. 1980. Двустворчатые моллюски семейства Corbiculidae Средней Азии // Зоологический журнал. Т. 59, вып. 8. С. 1130-1136.

Иззатуллаев 3.И. 1983. Экологические группировки пресноводных моллюсков Средней Азии // Моллюски. Систематика, экология, закономерности распространения. Сборник 7. Л.: Наука. С. $132-135$.

Иззатуллаев 3.И. 1987. Водные моллюски Средней Азии и сопредельных территорий (состав, особенности образа жизни, распространения, зоогеография и история формирования фауны, хозяйственное значение). Диссертация ... доктора биол. наук. Л.-Душанбе: ЗИН АН СССР. 97 с.

Иззатуллаев 3.И. 2019. Фауна моллюсков водных экосистем Средней Азии и сопредельных территорий. Ташкент: «LESSON PRESS». $228 \mathrm{c}$.

Иззатуллаев 3.И., Боймурадов Х.Т. 2009. Зарафшон дарёси хавзаси икки паллали моллюскалари. Самарканд: СамДУ. 95 с.

Иззатуллаев З.И., Круглов Н.Д., Старобогатов Я.И. 1983. Новые и малоизвестные виды прудовиков подрода Radix рода Lymnaea фауны СССР из Средней Азии (Gastropoda, Pulmonata) // Известия АН Таджикской ССР. Отделение биологических наук. № 4 (93). С. 53-57. 
Круглов Н.Д. 2005. Моллюски семейства прудовиков (Lymnaeidae, Gastropoda, Pulmonata) Европы и Северной Азии (особенности экологии и паразитологическое значение). Смоленск. Изд-во СПТУ. 507 c.

Курсалова В.И., Старобогатов Я.И. 1971. Моллски рода Corbicula антропогена северной и западной Азии и Европа // Моллюски. Пути, методы и итоги их изучения. Сборник 4. М.-Л.: Наука. С. 93-96.

Лазарева А.И. 1967. К систематике прудовиков семейства Lymnaeidae (Gastropoda, Pulmonata) Казахстана // Труды Зоологического института АН СССР. Т. 42. С.198-204.

Павлова М.В. 1964. Зообентос заливов озера Иссык-куль и его использование рыбами. Фрунзе: Илим. $85 \mathrm{c.}$

Пивиаев С.Г., Иззатуллаев З.И., Мирабдуллаев И.М. 2001. Запасы беззубок (Bivalvia, Unionidae) среднего течения реки Сырдарья // Проблемы охраны рационального использования биологических ресурсов водоёмов Узбекистана. Ташкент: «Chinor ENK». С. 83-87.

Прозорова Л.А. 1991. Морфология кладок брюхоногих моллюсков Приморского края // Труды Зоологического института АН СССР. Т. 228. С. 74-110.

Проскурина Е.С. 1979. О линейном и весовом росте основных видов двустворчатых моллюсков Аральского моря // Гидробиологический журнал. Т. 15, вып. 5. С. 105-106.

Старобогатов Я.И. 1974. Тип моллюски Mollusca // Атлас беспозвоночных Аральского моря. М.: Пищевая промышленность. С. 237-248, 253-257.

Старобогатов Я.И., Иззатуллаев 3.И. 1980. Моллюски сем. Melanoididae (Gastropoda, Pectinibranchia) Средней Азии и сопредельных территорий // Зоологический журнал. Т. 59, вып. 1. C 23-31.

Старобогатов Я.И., Прозорова Л.А., Богатов В.В., Саенко Е.М. 2004. Моллюски // Определитель пресноводных беспозвоночных России и сопредельных территорий. Том 6. С.-Пб.: Наука. C. 9-491.

Хусаинова Н.3. 1954. Зообентос Аральского моря // Труды Лаборатории озероведения АН СССР. T. 3. C. $77-85$.

Habe T. 1977. Systematics of Mollusca in Japan. Bivalvia and Scaphopoda. Tokyo: Hokuryukan. 360 p.

Joosse J., Boer M.H., Cornelisse C.J. 1968. Gametogenesis and oviposition in Lymnaea stagnalis as influenced by Y-irradiation and hunger // Symposia of the Zoological Society of London. N 22. P. $213-235$.

Klimowicz M. 1959. Tentative classification of small water hoides on the basis of the differentiation of the molluscan fauna // Polskie Archiwum Hydrobiologii. V. 6, N 9. P. 85-103.

Korniushin A.V. 2004. A revision of some Asian and African freshwater clams assigned to Corbicula fluminalis (Muller, 1774) (Mollusca: Bivalvia: Corbiculidae), with a review of anatomical characters and reproductive features based on museum collections // Hydrobiologia. V. 529. P. 251-270.

Published online December 25, 2020 